\title{
UJI EFEKTIVITAS PUPUK ORGANONITROFOS DAN KOMBINASINYA DENGAN PUPUK KIMIA PADA TANAMAN JAGUNG DI TANAH ULTISOL GEDUNG MENENG
}

\author{
Azanu Rudit Septima, Jamalam Lumbanraja, Dermiyati \& Sutopo Ghani Nugroho \\ Jurusan Agroteknologi, Fakultas Pertanian Universitas Lampung \\ Jl. Prof. Soemantri Brodjonegoro, No. 1, Bandar Lampung 35145 \\ E-mail: azanu.rudit.s@gmail.com
}

\begin{abstract}
ABSTRAK
Organonitros merupakan pupuk organik formula baru yang perlu diuji efektivitas aplikasi pupuk tersebut terhadap tanaman, khususnya tanaman pangan dan hortikultura. Dalam hal ini, ujiefektivitas aplikasi pupuk Organonitrofos, dikombinasikan dengan pupuk kimia, dilakukan terhadap pertumbuhan dan produksi tanaman jagung. Penelitian ini bertujuan untuk mengetahui kombinasi dosis pupuk Organonitrofos dan pupuk kimia yang paling mempengaruhi pertumbuhan, serapan hara dan produksi tanaman jagung dan menguji efektivitas pupuk Organonitrofos terhadap pertumbuhan, serapan hara dan produksi tanaman jagung. Percobaan plot (plot experiment) dengan tanaman jagung dilakukan di Kebun Laboratorium Lapang Terpadu Pakultas Pertanian Unila di Gedung Menang. Percobaan dilakukan dalam Rancangan Acak Kelompok, dengan 6 perlakuan dan ulangan 3. Ukuran petak percobaan 3 x 3 m. Perlakuan percobaan meliputi: Kontrol (tanpa pupuk); 100\% pupuk kimia rekomendasi; 10\% substitusi dengan Organitrofos; 20\% substitusi dengan Organitrofos;40\% substitusi dengan Organitrofos; dan $100 \%$ pupuk Organonitrofos. Hasil percobaan menunjukkan bahwa dari performance pertumbuhan tanaman (bobot brangkasan) dan produksi jagung (bobot pipilan kering dan bobot seratus butir) terbukti secara konsisten perlakuan kombinasi pupuk kimia dengan Organonitrofos, yaitu substitusi sebagian pupuk kimia anjuran dengan pupuk Organonitrofos sebesar $40 \%$, menghasilkan berangkasan tanaman, produksi pipilan kering, dan bobot seratus butir jagung tertinggi, diikuti pada peringkat kedua oleh perlakuan $100 \%$ pupuk Organonitrofos tanpa kombinasi dengan pupuk kimia
\end{abstract}

Kata Kunci: Jagung, Kombinasi Pupuk Kimia dan Organik, Organonitrofos, Respons Tanaman, Uji Efektivitas Pupuk.

\section{PENDAHULUAN}

Selama ini penggunaan pupuk buatan sangat dominan. Telah disadari bahwa pemupukan kimia yang berkelanjutan berdampak negatif terhadap tanah, baik fisik, kimia, dan biologi. Disamping itu, karena pembuatan pupuk kimia berbahan baku fosil dan bahan lain yang masih diimpor, maka harga pupuk kimia semakin mahal sehingga sulit terjangkau oleh petani, kalau tidak disubsidi oleh pemerintah. Di pihak lain, semakin intensif penggunaan suatu lahan, maka kandungan bahan organik tanah akan semakin rendah.

Kelemahan pupuk kimia tersebut (harga mahal, dampak negatif dan distribusi tidak lancar) dapat diatasi dengan menggalakkan kembali penggunaan pupuk organik (go organic). Diketahui bahwa pupuk organik mempunyai banyak keunggulan terhadap perbaikan kualitas tanah. Pupuk organik dapat dikembangkan dari bahan baku lokal, sehingga harga pupuk diharapkan akan murah. Tetapi saat ini kualitas pupuk organik yang tersedia di pasar umumnya kurang memadai, karena menyediakan unsur hara $\mathrm{N}$ dan tidak menyediakan hara mineral lainnya yang cukup, khususnya $\mathrm{P}$.
Nugroho, dkk. (2012) memformulasi/merakit pupuk organik baru dengan mencampurkan bahan organik berupa campuran kotoran sapi segar (fresh manure) dan tepung batuan fosfat (rock phosphate) dengan rasio 75-80\% : 25-20\% yang ditambahkan/ diinokulasi dengan mikroba penambat $\mathrm{N}\left(\mathrm{N}_{2}\right.$ fixer $)$ dan mikroba pelarut fosfat ( $P$-solubilizer). Pupuk yang dihasilkan dinamai Organonitrofos yang diharapkan kandungan $\mathrm{N}$ dan $\mathrm{P}$ cukup memadai. Kedua bahan baku pupuk ini juga tersedia cukup banyak di Provinsi Lampung.

Karena pupuk organonitros merupakan formula pupuk baru, perlu dilakukan uji efektivitas aplikasi pupuk tersebut terhadap tanaman, khususnya tanaman pangan. Dalam hal ini, uji efektivitas aplikasi pupuk Organonitrofos yang dikombinasikan dengan pupuk kimia dilakukan terhadap pertumbuhan dan produksi tanaman jagung. Karena menurut Saidah dan Syafruddin (2006), kombinasi pemberian 50\% pupuk anorganik dan $50 \%$ pupuk organik memberikan pengaruh yang terbaik terhadap produksi tanaman padi.

Penelitian ini bertujuan untuk mengetahui kombinasi dosis pupuk Organonitrofos dan pupuk kimia 
yang paling mempengaruhi pertumbuhan, serapan hara dan produksi tanaman jagung dan menguji efektivitas pupuk Organonitrofos terhadap pertumbuhan, serapan hara dan produksi tanaman jagung

\section{BAHAN DAN METODE}

Desain perlakuan pupuk untuk uji respons tanaman jagung terhadap aplikasi pupuk Organonitrofos tertera pada Tabel 1. Percobaan dilakukan dengan Rancangan Acak Kelompok dengan 6 perlakuan dan 3 ulangan. Percobaan plot dengan tanaman jagung dilakukan di Kebun Laboratorium Lapang Terpadu Fakultas Pertanian Unila di Gedung Meneng.

Persiapan plot dimulai dengan pembersihan lahan, pembuatan petakan (plot) ukuran $3 \times 3$ meter, tanah diambil contoh awal, kemudian diolah dengan cangkul. Benih jagung P21 ( 2 benih) ditanam di dalam lubang tugal dengan jarak tanam $70 \times 25 \mathrm{~cm}$. Pada saat penanaman, pupuk Organonitrofos, SP-36, dan $\mathrm{KCl}$ diaplikasikan sedangkan pupuk urea diaplikasikan dua kali yaitu $1 / 2$ dosis pada 1 MST dan pada saat berbunga $1 / 2$ dosis sisanya. Penjarangan dilakukan setelah tanaman berumur 6 hari sehingga tersisa satu tanaman yang tumbuh sehat. Selama pemeliharaan dilakukan pengairan karena pada musim tanam ini adalah musim kemarau.
Pengairan dilakukan sekali sehari yaitu sore hari. Pembumbunan yang bertujuan untuk memperkokoh pertumbuhan jagung dilakukan saat tanaman berumur 4 minggu. Penyiangan gulma dilakukan seperlunya dengan mencabut gulma dari plot percobaan serta aplikasi pestisida seperlunya.

Panen jagung dilakukan setelah tanaman berumur sekitar 120 hari. Kadar air pipilan jagung diukur dan kemudian dikonversi menjadi 15\% kadar air. Variabel utama yang diamati meliputi: tinggi tanaman, berat pipilan kadar air 15\%, bobot tongkol, berat berangkasan, serapan hara tanaman serta RAE (Relative Agronomic Effectiveness).

\section{HASIL DAN PEMBAHASAN}

Sifat kimia tanah tempat percobaan yang diambil pada awal percobaan dan sifat kimia pupuk organonitrofos tertera pada Tabel 2 . Hasil analisis tanah percobaan menunjukkan bahwa $\mathrm{pH}$ tanah termasuk agak masam, kandungan $\mathrm{C}$-organik yang rendah, $\mathrm{N}$-total 0,23\% dan P-total 326,85 ppm, P-tersedia 8,6 ppm (sedang), dan K-dd tergolong tinggi. Hasil analisis pupuk organonitrofos memliki kemasaman agak alkalis, kandungan C-organik $21,51 \%, \mathrm{~N}$-total 1,32\%, P-total $\mathrm{HCl} 25 \% 3360,21 \mathrm{ppm}$, dan $\mathrm{K}_{2} \mathrm{O} 4860,18$ ppm.

Tabel 1. Perlakuan pupuk untuk uji respons tanaman jagung $\left(\mathrm{kg} \mathrm{ha}^{-1}\right)$.

\begin{tabular}{llcccc}
\hline No & \multicolumn{1}{c}{ Perlakuan/pupuk } & Urea & SP-36 & $\mathrm{KCl}$ & Organik \\
\cline { 3 - 6 } & & $. \quad . \quad$. & $\mathrm{kg} \mathrm{ha}^{-1}$ & $. \quad . \quad . \quad$ \\
\hline 1 & Kontrol (tanpa pupuk) & 0 & 0 & 0 & 0 \\
2 & $100 \%$ pupuk kimia rekomendasi & 900 & 250 & 250 & 0 \\
3 & Substitusi 10\% Organonitrofos & 600 & 150 & 150 & 500 \\
4 & Substitusi 20\% Organonitrofos & 150 & 50 & 100 & 1000 \\
5 & Substitusi 40\% Organonitrofos & 100 & 50 & 100 & 2000 \\
6 & 100\% Organonitrofos & 0 & 0 & 0 & 5000 \\
\hline
\end{tabular}

Tabel 2. Sifat tanah tempat percobaan dan sifat pupuk organonitrofos.

\begin{tabular}{lccc}
\hline \multicolumn{1}{c}{ Analisis } & Tanah & Kriteria & Pupuk Organonitrofos \\
\hline $\mathrm{pH}\left(\mathrm{H}_{2} \mathrm{O}\right)$ & 6,00 & Agak masam & 7,60 \\
C-organik $(\%)$ & 1,80 & Rendah & 21,51 \\
N-total $(\%)$ & 0,23 & Sedang & 1,32 \\
P-total $\mathrm{HCl} \mathrm{25 \%} \mathrm{(ppm)}$ & 326,85 & Sedang & 3360,21 \\
K-total HCl 25\% (ppm) & 298,95 & Sedang & 4860,18 \\
P-tersedia Bray 1 (ppm) & 8,60 & Sedang & \\
K-dd (me 100 g - $\left.^{-1}\right)$ & 0,80 & Tinggi & \\
\hline
\end{tabular}

Sumber kriteria: Balai Penelitian Tanah, 2005 
Kandungan $\mathrm{N}$ dan $\mathrm{P}$ yang tinggi ini disebabkan proses penambatan dan pelarutan fosfat oleh bakteri yang diinokulasikan berjalan dengan sangat baik. Pemberian mikroba tersebut menjadi sangat efektif karena dicampurkan dengan kotoran hewan yang dapat mendukung perkembangan mikroorganisme tersebut. Hal ini sesuai dengan hasil penelitian Dermiyati $d k k$. (2009) bahwa keefektifan mikroorganisme pelarut fosfat dapat ditingkatkan dengan cara pemberian pupuk bokashi. Mikroorganisme dalam hal ini menggunakan pupuk bokashi sebagai sumber energi untuk mendukung perkembangbiakkan dan peningkatan aktivitas metabolisme.

Hasil penelitian (Gambar 1) menunjukkan bahwa semua perlakuan pemupukan tidak berbeda nyata terhadap tinggi tanaman. Hal ini diduga karena lahan yang digunakan dalam penelitian ini baru dibuka dari semak belukar. Lahan yang baru dibuka masih memiliki unsur hara yang lengkap karena terjadi proses penumpukan serasah daun yang terjadi secara terusmenerus dari vegetasi di atasnya. Serasah daun ini yang nantinya akan menjadi sumber unsur hara bagi tanah dan unsur hara ini akan dilepaskan kembali apabila pembersihan lahan dilakukan (Mulyoutami $d k k ., 2010$ ).

Namun perlakuan E $\left(100 \mathrm{~kg} \mathrm{ha}^{-1}\right.$ urea, $50 \mathrm{~kg}$ $\mathrm{ha}^{-1} \mathrm{SP} 36,100 \mathrm{~kg} \mathrm{ha}^{-1} \mathrm{KCl}, 2000 \mathrm{~kg} \mathrm{ha}^{-1}$ organonitrofos) dan F (5000 kg ha-1 organonitrofos) cenderung memiliki tinggi tanaman jagung tertinggi. Berdasarkan data pada Gambar 1 dapat disimpulkan bahwa pemberian pupuk organonitrofos, baik diaplikasikan sendiri maupun dikombinasikan dengan pupuk kimia dapat meningkatkan pertumbuhan tinggi tanaman dibandingkan dengan aplikasi pupuk kimia rekomendasi.

Perlakuan pemupukan baik tunggal maupun kombinasi tidak menunjukkan adanya interaksi nyata pada serapan hara tanaman. Walaupun demikian pemberian pupuk organonitrofos memperlihatkan serapan hara $\mathrm{N}$ yang hampir sama dengan pemupukan rekomendasi, dan peningkatan serapan hara $\mathrm{P}$ dibandingkan kontrol (Gambar 2).

Sedangkan serapan hara $\mathrm{P}$ dan $\mathrm{K}$ tertinggi diperoleh perlakuan $\mathrm{E}$ yaitu pemupukan kombinasi 100 kg urea ha- ${ }^{-1}, 50 \mathrm{~kg} \mathrm{SP} 36 \mathrm{ha}^{-1}, 100 \mathrm{~kg} \mathrm{KCl} \mathrm{ha}{ }^{-1}, 2000 \mathrm{~kg}$ organonitrofos ha ${ }^{-1}$. Hal ini berarti pupuk Organonitrofos mampu memberikan nutrisi yang cukup terhadap tanaman, sehingga hasil produksi meningkat juga (Gambar 2). Selain itu, pemberian bahan organik pada tanah masam dapat meningkatkan serapan $\mathrm{P}$ dan hasil tanaman jagung karena setelah bahan organik terdekomposisi akan menghasilkan beberapa unsur hara seperti N, P dan K serta menghasilkan asam humat dan fulvat yang memegang peranan penting dalam pengikatan $\mathrm{Fe}$ dan $\mathrm{Al}$ yang larut dalam tanah sehingga ketersediaan P akan meningkat (Hasanudin, 2003).

Berdasarkan data (Gambar 3), perlakuan E (100 $\mathrm{kg} \mathrm{ha}^{-1}$ urea, $50 \mathrm{~kg} \mathrm{ha}^{-1} \mathrm{SP} 36,100 \mathrm{~kg} \mathrm{ha}^{-1} \mathrm{KCl}, 2000 \mathrm{~kg}$ $\mathrm{ha}^{-1}$ organonitrofos) tetap menunjukkan hasil pipilan tertinggi dibandingkan perlakuan pemupukan yang lain.

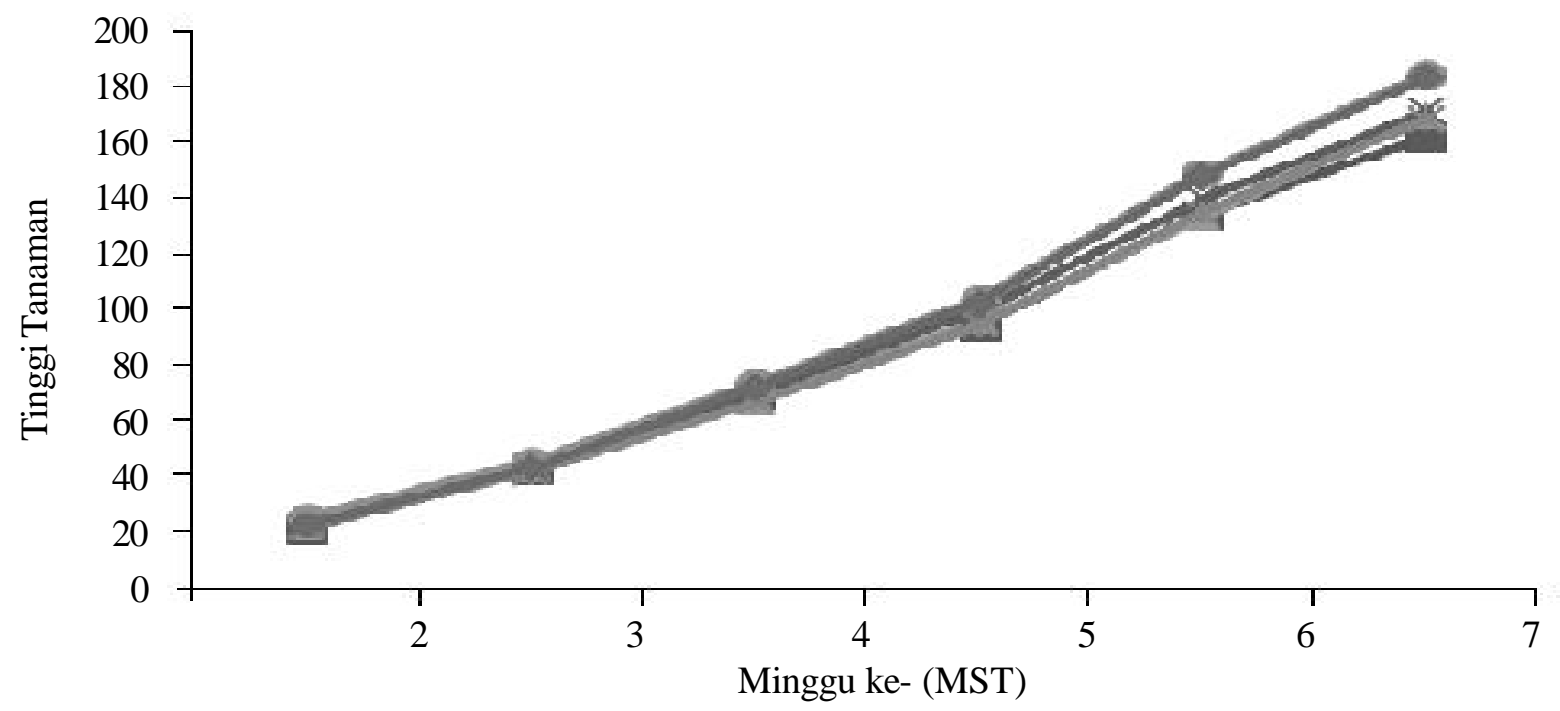

Gambar 1. Pengaruh pemupukan terhadap tinggi tanaman jagung. $\mathrm{A}(\boldsymbol{\square})=$ tanpa pemupukan, $\mathrm{B}(\mathbf{\Delta})=900 \mathrm{~kg}$ ha $^{-1}$ urea, $250 \mathrm{~kg} \mathrm{ha}^{-1} \mathrm{SP} 36,250 \mathrm{~kg} \mathrm{ha}^{-1} \mathrm{KCl}, \mathrm{C}(\mathrm{X})=600 \mathrm{~kg} \mathrm{ha}^{-1} \mathrm{urea}, 150 \mathrm{~kg} \mathrm{ha}^{-1} \mathrm{SP} 36,150 \mathrm{~kg} \mathrm{ha}^{-1} \mathrm{KCl}$, $500 \mathrm{~kg} \mathrm{ha}^{-1}$ Organonitrofos, D $(*)=150 \mathrm{~kg} \mathrm{ha}^{-1}$ urea, $50 \mathrm{~kg} \mathrm{ha}^{-1} \mathrm{SP} 36,100 \mathrm{~kg} \mathrm{ha}^{-1} \mathrm{KCl}, 1000 \mathrm{~kg} \mathrm{ha}^{-1}$ organonitrofos, $\mathrm{E}(\bullet)=100 \mathrm{~kg} \mathrm{ha}^{-1}$ urea, $50 \mathrm{~kg} \mathrm{ha}^{-1} \mathrm{SP} 36,100 \mathrm{~kg} \mathrm{ha}^{-1} \mathrm{KCl}, 2000 \mathrm{~kg} \mathrm{ha}^{-1}$ organonitrofos, $\mathrm{F}(\diamond)=5000 \mathrm{~kg} \mathrm{ha}^{-1}$ organonitrofos. 


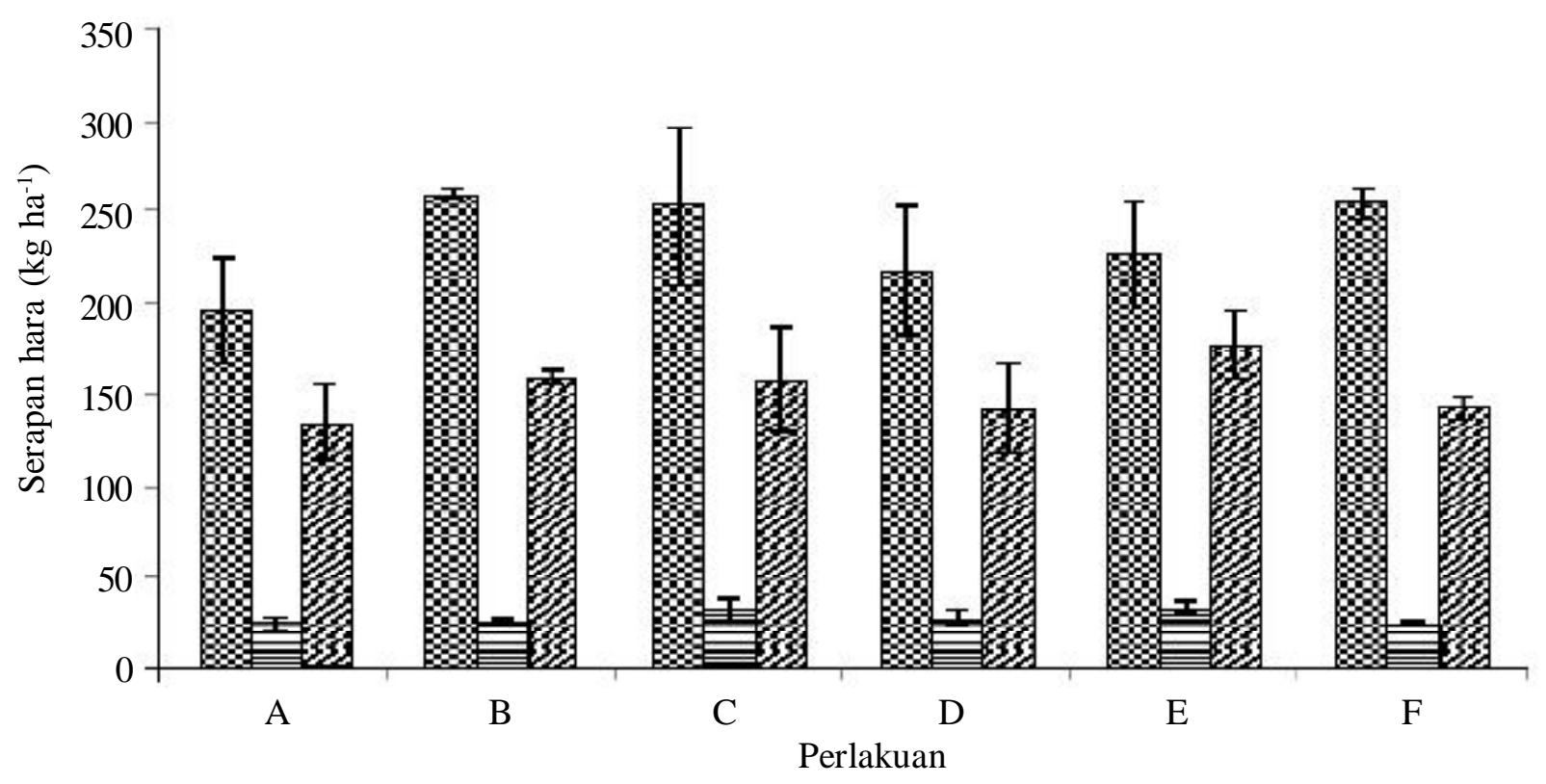

Gambar 2. Pengaruh pemupukan terhadap serapan total N, P dan $\mathrm{K}$ pada tanaman jagung. $\mathrm{A}=$ tanpa pemupukan, $\mathrm{B}=900 \mathrm{~kg} \mathrm{ha}^{-1}$ urea, $250 \mathrm{~kg} \mathrm{ha}^{-1} \mathrm{SP} 36,250 \mathrm{~kg} \mathrm{ha}^{-1} \mathrm{KCl}, \mathrm{C}=600 \mathrm{~kg} \mathrm{ha}^{-1}$ urea, $150 \mathrm{~kg} \mathrm{ha}^{-1} \mathrm{SP} 36,150 \mathrm{~kg}$ $\mathrm{ha}^{-1} \mathrm{KCl}, 500 \mathrm{~kg} \mathrm{ha}^{-1}$ organonitrofos, D = $150 \mathrm{~kg} \mathrm{ha}^{-1}$ urea, $50 \mathrm{~kg} \mathrm{ha}^{-1} \mathrm{SP} 36,100 \mathrm{~kg} \mathrm{ha}^{-1} \mathrm{KCl}, 1000 \mathrm{~kg}$ ha $^{-1}$ organonitrofos, $\mathrm{E}=100 \mathrm{~kg} \mathrm{ha}^{-1} \mathrm{urea}, 50 \mathrm{~kg} \mathrm{ha}^{-1} \mathrm{SP} 36,100 \mathrm{~kg} \mathrm{ha}^{-1} \mathrm{KCl}, 2000 \mathrm{~kg} \mathrm{ha}^{-1}$ organonitrofos,

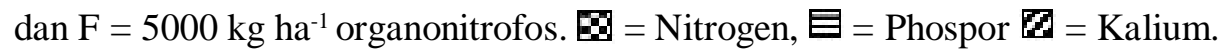

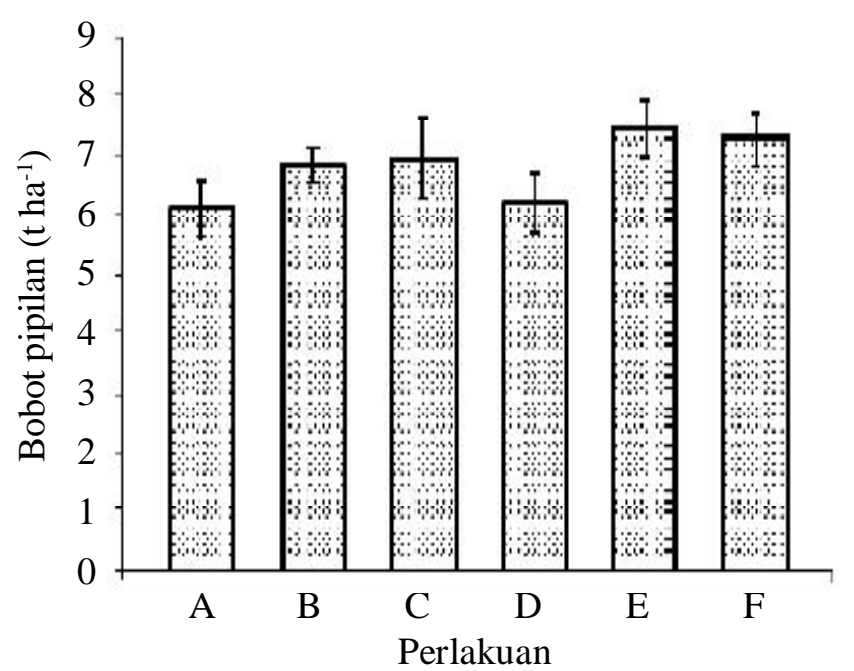

Gambar 3. Pengaruh pemupukan terhadap bobot pipilan jagung. $\mathrm{A}=$ tanpa pemupukan, $\mathrm{B}=900 \mathrm{~kg}$ ha ${ }^{-1}$ urea, $250 \mathrm{~kg} \mathrm{ha}^{-1} \mathrm{SP} 36,250 \mathrm{~kg} \mathrm{ha}^{-1} \mathrm{KCl}$, $\mathrm{C}=600 \mathrm{~kg} \mathrm{ha}^{-1}$ urea, $150 \mathrm{~kg} \mathrm{ha}^{-1} \mathrm{SP} 36,150$ $\mathrm{kg} \mathrm{ha}{ }^{-1} \mathrm{KCl}, 500 \mathrm{~kg} \mathrm{ha}^{-1}$ organonitrofos, $\mathrm{D}=150 \mathrm{~kg} \mathrm{ha}^{-1}$ urea, $50 \mathrm{~kg} \mathrm{ha}^{-1} \mathrm{SP} 36,100 \mathrm{~kg}$ $\mathrm{ha}^{-1} \mathrm{KCl}, 1000 \mathrm{~kg} \mathrm{ha}^{-1}$ organonitrofos, $\mathrm{E}=100 \mathrm{~kg} \mathrm{ha}^{-1}$ urea, $50 \mathrm{~kg} \mathrm{ha}^{-1} \mathrm{SP} 36,100 \mathrm{~kg}$ ha $^{-1} \mathrm{KCl}, 2000 \mathrm{~kg} \mathrm{ha}^{-1}$ organonitrofos, dan $\mathrm{F}=5000 \mathrm{~kg} \mathrm{ha}^{-1}$ organonitrofos.

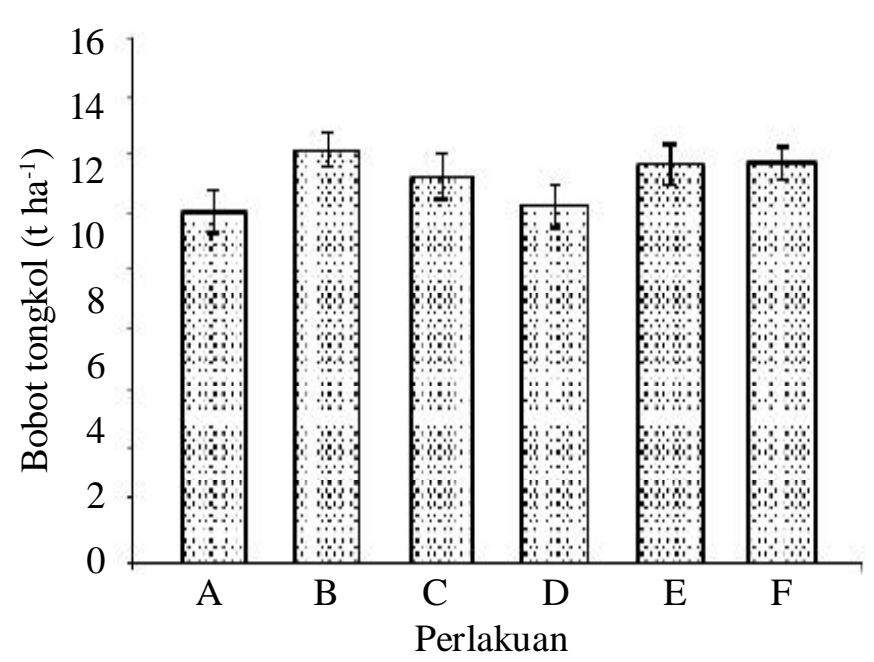

Gambar 4. Pengaruh pemupukan terhadap bobot tongkol jagung. $\mathrm{A}=$ tanpa pemupukan, $\mathrm{B}=900 \mathrm{~kg}$ ha $^{-1}$ urea, $250 \mathrm{~kg} \mathrm{ha}^{-1} \mathrm{SP} 36,250 \mathrm{~kg} \mathrm{ha}^{-1} \mathrm{KCl}$, $\mathrm{C}=600 \mathrm{~kg} \mathrm{ha}^{-1}$ urea, $150 \mathrm{~kg} \mathrm{ha}^{-1} \mathrm{SP} 36,150$ $\mathrm{kg} \mathrm{ha}^{-1} \mathrm{KCl}, 500 \mathrm{~kg} \mathrm{ha}^{-1}$ organonitrofos, $\mathrm{D}=150 \mathrm{~kg} \mathrm{ha}^{-1}$ urea, $50 \mathrm{~kg} \mathrm{ha}^{-1} \mathrm{SP} 36,100 \mathrm{~kg}$ $\mathrm{ha}^{-1} \mathrm{KCl}, 1000 \mathrm{~kg} \mathrm{ha}^{-1}$ organonitrofos, $\mathrm{E}=100 \mathrm{~kg} \mathrm{ha}^{-1}$ urea, $50 \mathrm{~kg} \mathrm{ha}^{-1} \mathrm{SP} 36,100 \mathrm{~kg}$ $\mathrm{ha}^{-1} \mathrm{KCl}, 2000 \mathrm{~kg} \mathrm{ha}^{-1}$ organonitrofos, dan $\mathrm{F}=5000 \mathrm{~kg} \mathrm{ha}^{-1}$ organonitrofos. 
Hal yang sama terlihat pada perlakuan F $\left(5000 \mathrm{~kg} \mathrm{ha}^{-1}\right.$ organonitrofos) tetap menunjukkan hasil yang lebih tinggi dibandingkan dengan perlakuan pemupukan rekomendasi. Penelitian Yamika dan Ikawati (2012) menunjukkan aplikasi pupuk kimia dengan pupuk organik secara nyata meningkatkan produksi kedelai (jumlah bunga, jumlah polong, bobot 100 butir dan hasil per hektar).

Pemupukan rekomendasi (900 kg ha-1 urea, 250 $\left.\mathrm{kg} \mathrm{ha}^{-1} \mathrm{SP} 36,250 \mathrm{~kg} \mathrm{ha}^{-1} \mathrm{KCl}\right)$ menghasilkan bobot tongkol tertinggi yaitu 13,49 $\mathrm{t} \mathrm{ha}^{-1}$ (Gambar 4). Namun hasil tersebut tidak berbeda nyata dibandingkan dengan pemupukan dengan $5000 \mathrm{~kg} \mathrm{ha}^{-1}$ organonitrofos sebesar 13,06 $\mathrm{t} \mathrm{ha}^{-1}$ (Gambar 4). Hal yang sama terlihat dalam penelitian Ayeni dkk., (2012) bahwa pupuk organomineral dengan dosis 5 tha $^{-1}$ menunjukkan jumlah daun, berangkasan dan produksi tertinggi pada jagung. Hal ini mengindikasikan bahwa pemupukan dengan pupuk organonitrofos dapat mensubstitusi pupuk kimia. Hasil produksi yang tinggi dari perlakuan pupuk organonitrofos dapat disebabkan pupuk ini adalah pupuk organik berkualitas tinggi. Pupuk organik berkualitas tinggi, artinya proses laju dekomposisi dan mineralisasi berjalan cepat setelah dibenamkan kedalam tanah, sehingga mampu melepaskan hara juga dengan cepat (Martajaya, 2009).

Hasil penelitian (Gambar 5) menunjukkan bahwa perlakuan pemupukan E (100 kg ha-1 urea, $50 \mathrm{~kg} \mathrm{ha}^{-1}$ SP36, $100 \mathrm{~kg} \mathrm{ha}^{-1} \mathrm{KCl}, 2000 \mathrm{~kg} \mathrm{ha}^{-1}$ organonitrofos) memberikan hasil bobot berangkasan tertinggi. Begitu juga dengan pemupukan organonitrofos yang menunjukkan hasil yang lebih baik dibandingkan pemupukan kimia rekomendasi. Berdasarkan hasil tersebut, kombinasi antara pupuk kimia dan organonitrofos dapat meningkatkan pertumbuhan serta produksi jagung, baik dari hal tinggi tanaman, bobot pipilan jagung, serta bobot berangkasan tanaman. Tingginya hasil produksi pada perlakuan kombinasi E dibandingkan perlakuan lainnya diduga karena sifat tanah pada perlakuan E mampu menunjang pertumbuhan serta produksi jagung. Kondisi ini menyebabkan penyerapan pupuk kimia oleh tanaman lebih efisien. Pupuk organonitrofos dengan dosis $2000 \mathrm{~kg} \mathrm{ha}^{-1}$ cukup mempersiapkan tanah yang kondusif untuk penyerapan pupuk kimia oleh tanah.

Relative Agronomic Effectiveness (RAE) adalah perbandingan antara kenaikan hasil karena penggunaan pupuk yang sedang diuji dengan kenaikan hasil pada pupuk standar dikalikan 100\% (Mackay $d k k .$, 1984). Hasil analisis Relative Agronomic Effectiveness (Tabel 3) menunjukkan bahwa penggunaan pupuk Organonitrofos tunggal maupun kombinasi dengan pupuk

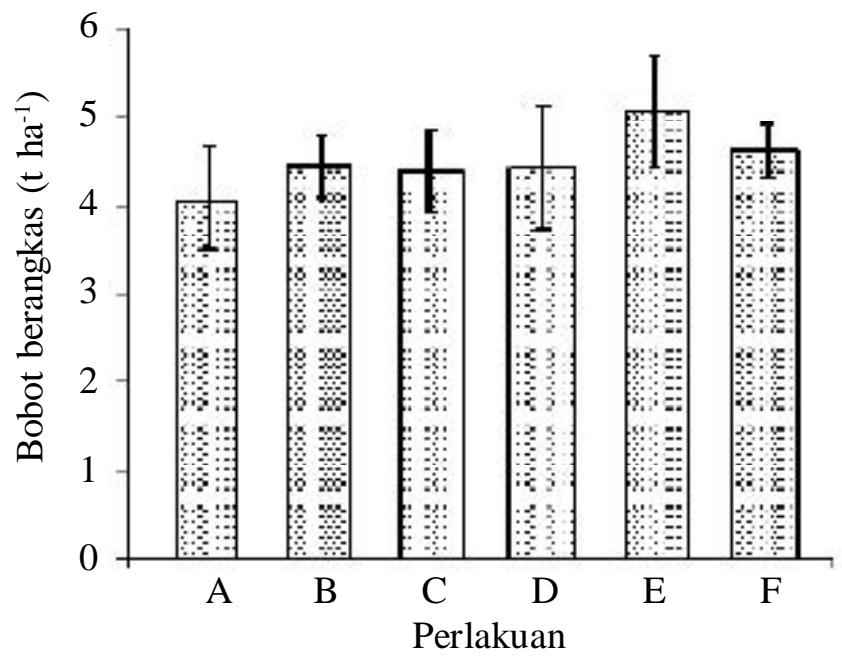

Gambar 5. Pengaruh pemupukan terhadap bobot berangkas jagung. $\mathrm{A}=$ tanpa pemupukan, $\mathrm{B}=900 \mathrm{~kg} \mathrm{ha}^{-1} \mathrm{urea}, 250 \mathrm{~kg} \mathrm{ha}^{-1} \mathrm{SP} 36,250$ $\mathrm{kg} \mathrm{ha}^{-1} \mathrm{KCl}, \mathrm{C}=600 \mathrm{~kg} \mathrm{ha}^{-1}$ urea, $150 \mathrm{~kg}$ $\mathrm{ha}^{-1} \mathrm{SP} 36,150 \mathrm{~kg} \mathrm{ha}^{-1} \mathrm{KCl}, 500 \mathrm{~kg} \mathrm{ha}^{-1}$ organonitrofos, $\mathrm{D}=150 \mathrm{~kg} \mathrm{ha}^{-1}$ urea, $50 \mathrm{~kg}$ ha $^{-1}$ SP36, $100 \mathrm{~kg} \mathrm{ha}^{-1} \mathrm{KCl}, 1000 \mathrm{~kg} \mathrm{ha}^{-1}$ organonitrofos, $\mathrm{E}=100 \mathrm{~kg} \mathrm{ha}^{-1} \mathrm{urea}, 50 \mathrm{~kg}$ ha $^{-1}$ SP36, $100 \mathrm{~kg} \mathrm{ha}^{-1} \mathrm{KCl}, 2000 \mathrm{~kg} \mathrm{ha}^{-1}$ organonitrofos, dan $\mathrm{F}=5000 \mathrm{~kg} \mathrm{ha}^{-1}$ organonitrofos.

kimia mampu meningkatkan RAE antara 10-74\% lebih tinggi dibandingan dengan penggunaan pupuk kimia rekomendasi. Hal ini menunjukkan bahwa secara agronomi penggunaan pupuk Organonitrofos tunggal maupun kombinasi dengan pupuk kimia dapat digunakan sebagai alternatif pengganti pupuk kimia tunggal dalam budidaya jagung.

\section{KESIMPULAN}

Hasil penelitian pemberian pupuk Organonitrofos serta kombinasinya dengan pupuk kimia menunjukkan tidak adanya pengaruh yang nyata terhadap semua variabel pengamatan. Namun dari performance pertumbuhan tanaman (tinggi tanaman) dan produksi jagung (bobot pipilan kering) terbukti secara konsisten bahwa perlakuan kombinasi pupuk kimia dengan Organonitrofos, yaitu substitusi sebagian pupuk kimia anjuran dengan pupuk Organonitrofos sebesar 40\%, menghasilkan berangkasan tanaman, produksi pipilan kering jagung tertinggi, diikuti pada peringkat kedua oleh perlakuan dengan $100 \%$ pupuk Organonitrofos tanpa kombinasi dengan pupuk kimia. Pupuk organonitrofos dosis $5000 \mathrm{~kg} \mathrm{ha}^{-1}$ dan kombinasi $100 \mathrm{~kg} \mathrm{ha}^{-1}$ urea, $50 \mathrm{~kg}$ ha $^{-1}$ SP 36, $100 \mathrm{~kg} \mathrm{ha}^{-1} \mathrm{KCl}, 2000 \mathrm{~kg} \mathrm{ha}^{-1}$ organonitrofos 
Tabel 3. RAE pengaruh pemberian pupuk organonitrofos dan kombinasinya dengan pupuk kimia terhadap bobot pipilan jagung kering.

\begin{tabular}{lcc}
\hline $\begin{array}{c}\text { Perlakuan }\left(\mathrm{kg} \mathrm{ha}^{-1}\right) \\
\text { Urea }-\mathrm{SP} 36-\mathrm{KCl}-\text { Organonitrofos }\end{array}$ & $\begin{array}{c}\text { Pipilan kering } \\
\left(\mathrm{t} \mathrm{ha}^{-1}\right)\end{array}$ \\
\hline A $(0-0-0-0)$ & 6,08 & - \\
B $(900-250-250-0)$ & 6,86 & - \\
C $(600-150-150-500)$ & 6,94 & $110,26 \%$ \\
D $(150-50-100-1000)$ & 6,20 & $15,00 \%$ \\
E $(100-50-100-2000)$ & 7,44 & $174,36 \%$ \\
F $(0-0-0-5000)$ & 7,26 & $151,28 \%$ \\
\hline
\end{tabular}

efektif dalam meningkatkan pertumbuhan dan produksi tanaman jagung sebesar 51-74\%.

\section{UCAPAN TERIMA KASIH}

Terimakasih disampaikan kepada Direktorat Jendral Pendidikan Tinggi yang telah memberikan bantuan dana Riset Unggulan Strategis Nasional Tahun 2011-2012.

\section{DAFTAR PUSTAKA}

Ayeni, L.S., E. O. Adeleye dan J. O. Adejumo. Comparative Effect of Organic, Organomineral and Mineral Fertilizers on Soil Properties, Nutrient Uptake, Growth and Yield of Maize (Zea mays). Int. Res. J. Agric. Sci. Soil Sci. 2(11): 493-497.

Balai Penelitian Tanah. 2005. Petunjuk Teknis: Analisis Kimia Tanah, Tanaman, Air dan Pupuk. Departemen Pertanian. Bogor. $136 \mathrm{hlm}$.

Dermiyati, J. Antari, S. Yusnaini, dan S. G. Nugroho. 2009. Perubahan Populasi Mikroorganisme Pelarut Fosfat pada Lahan Sawah dengan Sistem Pertanian Intensif menjadi Pertanian Organik Berkelanjutan. J. Tanah Trop. 14 (2): 143-148.

Hasanudin. 2003. Peningkatan Ketersediaan dan Serapan N dan P serta Hasil Tanaman Jagung melalui Inokulasi Mikoriza, Azotobacter dan Bahan Organik pada Ultisol. Jurnal Ilmu Pertanian Indonesia. 5 (2): 83-89.
Mackay, A. D., J. K. Syers, dan P. E. H. Gregg. 1984. Ability of Chemical Extraction Procedures to Assess the Agronomic Effectiveness of Phosphate Rock Materials. New Zealand Journal of Agricultural Research 27: 219-230.

Martajaya, M. 2009. Pertumbuhan dan Hasil Jagung Manis (Zea Mays Saccharata Stury) yang Dipupuk dengan Pupuk Organik dan Anorganik pada Saat yang Berbeda. Jurnal Crop Agro 2(2): 90-100.

Mulyoutami, E., M. van Noordwijk., N. Sakuntaladewi, dan F. Agus, F. 2010. Perubahan Pola Perladangan: Pergeseran persepsi mengenai para peladang di Indonesia. Bogor, Indonesia. World Agroforestry Centre - ICRAF, SEA Regional Office. $101 \mathrm{hlm}$.

Nugroho, S. G., Dermiyati, J. Lumbanraja, S. Triyono, H. Ismono, Y. T. Sari, and E. Ayuandari. 2012. Optimum Ratio of Fresh Manure and Grain Size of Phosphate Rock Mixture in a Formulated Compost for Organomineral NP Fertilizer. $J$. Trop. Soils 17(2):121-128.

Saidah, D. B. dan Syafruddin. 2006. Pemanfaatan Pupuk Kandang dan Anorganik pada Padi Sawah dalam Sistem Integrasi Padi-ternak di Sulawesi Tengah. Jurnal Agrisains 7(2):95-100.

Yamika, W. S. D. dan K. R. Ikawati. 2012. Combination Inorganic and Organic Fertilizer Increased Yield Production of Soybean in Rain-Field Malang, Indonesia. Am.-Eurasian J. Sustain. Agric 6 (1): 14-17. 